\title{
Defragmenting the effect of major news announcements on financial markets
}

\author{
Ikhlaas Gurrib $\mathrm{a}^{*}$ \\ a Coordinator, MBA (Finance) program, Canadian University of Dubai, Dubai, \\ United Arab Emirates. \\ *Corresponding author e-mail: ikhlaas@cud.ac.ae.
}

\section{H I G H L I G H T S:}

1. The effects of major announcements released by the Central Bank on major currency pairs, all paired against the US Dollar, have been investigated.

2. Effect of the major announcement on three major currency pairs were calculated using a 1 minute analysis post announcement data.

3. Announcements to affect local currency relatively more than foreign currencies.

4. Stability diagnostic tests between the changes in EUR/USD against AUD/USD following news announcements do not reveal the presence of significant breakpoint tests.

\begin{tabular}{ll} 
Article History & ABSTRACT \\
\hline $\begin{array}{l}\text { Received: 12-03-2014 } \\
\text { Accepted: 18-04-2014 }\end{array}$ & $\begin{array}{l}\text { The issue of High Frequency Trading (HFT) and its impact on financial markets is hitting the } \\
\text { headlines hard nowadays. This paper looks at the effects of three major news } \\
\text { announcements on two major currency pairs namely the Australian dollar against the US } \\
\text { dollar and the Euro against the US dollar. The three major news announcements are the cash } \\
\text { rate from the Reserve Bank of Australia, the minimum bid rate from European Central Bank }\end{array}$ \\
$\begin{array}{l}\text { Keywords: } \\
\text { (ECB) and the official bank rate from the Bank of England. A one minute data interval }\end{array}$ \\
$\begin{array}{l}\text { Manalysis is used over a time period of four years. Findings suggest the effects of the specific } \\
\text { News announcements; } \\
\text { Official bank rate. }\end{array}$ & $\begin{array}{l}\text { news under analysis to be insignificant for a trader to benefit from the fluctuations in the } \\
\text { two major currency markets. The use of other macroeconomic news or higher frequency } \\
\text { data is warranted to defragment the effects of major news announcements further. }\end{array}$
\end{tabular}

JEL Classification:

G14; G15; F47.

DOI: http://dx.doi.org/10.18533/jefs.v2i02.130

(C) 2014 The Authors. This is an open access article under the terms of the Creative Commons Attribution License 4.0, which allows use, distribution and reproduction in any medium, provided the original work is properly cited.

\subsection{Introduction}

The advancement in globalization has increased with the help of financial markets by allowing investors to invest their money across any industry in the globe through financial markets in the form of public equity or debt infrastructures. Extensive literature exists regarding the importance of financial markets to any economy. Agenor and Pereira da Silva (2012) presented reviews on arguments for and against attributing an explicit financial stability objective to monetary policy. The reviews were in the context where regulations can be made to prevent disruptive and costly financial crisis. Essentially, financial markets are places in which people and entities can trade financial securities, commodities, and other fungible items of value at low transaction costs and at prices that reflect supply and demand. They trade financial instruments which include mainly securities and derivatives. The key risk 
determinants of these securities are volatility of the market, performance of the organizations or institutions issuing these securities and individual risks. Financial derivatives being derived from the financial securities provide the advantage of leverage and hence have higher expected returns than securities but the corresponding risk is also higher with key risk determinants as volatility of market and efficiency of the leverage strategy adopted (Darskuviene, 2010). There are many factors that affect the stock price movements in the financial markets. These include the performance of the company, economic position, demand and supply in the industry, product response among the public among others. Along with these key economic variables, politics, events occurring in the industry or market or in the company also play a major role in stock price movements of the company. Any good or bad news about the company, any major policy change in the nation or economy or industry, any change in the corporate governance structure of the organization among other news would lead to immediate effects on the stock prices. Gurrib (2008), using recursive estimates, found major economic events in the 1990s to have no significant effects on hedgers' and speculators' trading decisions and risk attitude. While Laïdi (2008) findings support that market events have significant impact on the stock price movements, Gurrib (2010) showed that in major US futures markets, hedger and speculator volatilities have shown a tendency to decay over time in response to shocks, supporting the belief that both players are informed and react well to news volatility. Similarly, Poterba and Summers (1988) showed that a significant impact of volatility on the stock prices can only take place if shocks to volatility persists over a long time.

As discussed above, market events and industry changes tend to have some impacts, significant or not, on the financial markets. Major news announcements made by the Central banks of various nations or economic policy changes affecting the inflation rates, employment rate and other economic parameters would have a significant impact on the financial markets and their price movements. Savor and Wilson (2013) observed that the average returns of the financial stock markets of Unites States of America were performing higher on those days where economic parameters or macroeconomic variables were declared to the public. These factors include consumer price index, employment rate and statistics, decisions made by Federal committee on financial markets among others. Statistically, it is observed that $60 \%$ of the overall returns from the financial markets are earned just on $13 \%$ of the trading days.

This paper discusses the effects of major news announcements from three different sources, the Reserve Bank of Australia, the Bank of England, and the European Central Bank. Since there are many variables that affect financial markets globally, the scope of this paper will discuss one economic announcement from each source that usually has a high impact on the financial markets. This paper discusses the Cash Rate by the Reserve Bank of Australia whose currency is the Australian Dollar (hereinafter known as AUD); the Official Bank Rate by the Bank of England whose currency is the Pound Sterling (hereinafter known as GBP); the Minimum Bid Rate by the European Central Bank whose currency is the Euro (hereinafter known as EUR). The announcements taken into consideration in this paper are those that were made by the central banks of the relative currencies.

There are several ways to measure the effects of major news announcements in financial markets, and this paper will focus mainly on the foreign exchange rate between AUD and the United States Dollar (hereinafter known as USD), and between the EUR and the USD. The measurement will be in percentage change and it will be a comparison between the exchange rate at the time of the announcement and the exchange rate one minute later. Extensive literature on the use of high-frequency financial data are provided by Andersen (2000) and Gouriéroux and Jasiak (2001). The findings tend to be mix, where in some cases, one minute is considered enough time to measure the reactions of the market since most of the tools used today are automated and work on algorithms and react quickly to the announcements, while in other cases, it is merely an indication of where the market is heading but is not enough time to provide information about the full reaction of the market. The one minute gap is used to be in line with more recent research using high frequency data. Currently, the fifteen most traded currencies around the globe are United States Dollar, Euro, Japanese Yen, Pound Sterling, Australian Dollar, Swiss Franc, Canadian Dollar, Mexican Peso, Chinese Yuan, New Zealand Dollar, Swedish Krona, Russian Rouble, Hong Kong Dollar, Singapore Dollar, and the Turkish Lira, respectively, while all the other currencies together form $12.2 \%$ of the daily trades in currencies (BIS, 2013).The AUD/USD and EUR/USD are chosen since they are the only two currency pairs which have grown consistently in terms of global foreign exchange market turnover, during the period 2001 to 2013 as reported in BIS (2013). The rationale behind pursuing this study is that it bridges the gap in existing literature, to be the first one, using 1 minute interval data to analyse the possible effects of significant news announcements on major currency pairs. The policy implications of this study extend toward giving added information to policy makers such as the U.S. Commodity Futures Trading Commission (CFTC), U.S. Securities Exchange Commission (SEC), and the Australian Security Investment Commission (ASIC), about whether the markets are rigged due to high frequency trading systems following releases of news announcements. Insignificant movements in major currency pairs, following global news, would add value that HFT systems do not posit harmful market activities. For instance, during the May 62010 "Flash Crash", the Dow Jones Industrial Average plunged about 1000 points (about 9\%) only to recover those losses within minutes (Lin, 2013). As a regulatory response, the SEC and CFTC, as a joint committee, recommended that the Commissions require that the pause rules of the 
Exchanges and Financial Industry Regulatory Body (FINRA) be expanded to cover all but the most inactively traded listed equity securities, ETFs, and options and single stock futures on those securities (SEC, 2010).

The presence of the fifteen most traded currencies with fifteen or more potential major news announcements might cause a clash between announcements in which more than one announcement is made at the same time, or an announcement follows another announcement very quickly, thus making it difficult to measure which announcement affected the financial market. Therefore, a one minute gap between the announcement and the measurement has been seen to be ample and measure the automatic reactions based on algorithms without involving people's different analyses into the measurement, thereby creating more of a controlled environment for measurement. All the announcements that have been chosen measure the short term interest rates of their respective monetary authorities. The reasons that they have been chosen are for their importance in currency valuation and the prediction of rates in the future. The announcements had solid values and the responses were measured accurately, which made it clearer on how traders responded to the announcements made by the respective monetary authorities. The announcements that had more than one announcement at the same time or within a one minute gap were excluded because including them may affect the integrity of the data collected and the conclusion at the end of the report. The rest of the paper provides the research methodology and data composition, the analysis section and some conclusive remarks.

\subsection{Data and research methodology}

The data set has been collected through secondary sources using mainly Forex Factory, established in 2004, and is currently the most viewed forex-related website (Forexfactory, 2014).The website has been used to gather the different timings of the announcements, the sources of the announcements, the frequency of the announcement, what the announcements measure, what makes them important, and the usual expected effects that the announcements might have on the market. Once the type of the announcement, its date and time of release have been established based on (GMT -8:00) Pacific Time (US \& Canada), the next data source used was GAIN Capital, a company established in 1999 to provide investors with information and easy access to financial markets whose data archives go back to the 2000 period. The archives were used to determine the exchange rate between AUD/USD and EUR/USD at the dates and times of the announcements and then one minute after the announcements have been made.

\subsection{Analysis}

\subsection{Cash rate announcements}

Cash Rate is the term used in Australia for the bank rate and the rate of interest that the Reserve Bank of Australia (Central Bank) charges on overnight loans to commercial banks. This allows the Reserve Bank of Australia to adjust the interest rate in its economy. The announcement is made on the first Tuesday of every month except in January, and its usual effect is when the actual cash rate is higher than the forecasted, then it is generally better for the home currency (AUD). Short term interest is one of the most important factors in currency valuation, which helps investors to predict what will happen in the future. The main goal behind setting the Cash Rate is to keep the inflation rate stable between 2-3\%, which is in line with the country's inflation targeting policies. Graph 2 and Graph 3 show the effect of the Cash Rate announcements on the financial markets and the exchange rates of AUD/USD and EUR/USD respectively; while the third graph is a bar chart taken from Forex Factory showing the actual cash rates that have been announced by the Reserve Bank of Australia.

\begin{tabular}{|c|c|c|c|c|c|c|c|}
\hline \multicolumn{8}{|c|}{ Table 01: AUD and EUR 1 minute data post release of cash rate announcement } \\
\hline & & & AUD & AUD & EUR & EUR & EUR \\
\hline Date & $\begin{array}{r}\text { Time of } \\
\text { Announcement }\end{array}$ & $\begin{array}{r}\text { At } \\
\text { Time }\end{array}$ & $\begin{array}{r}1 \text { Minute } \\
\text { Later }\end{array}$ & Change & $\begin{array}{r}\text { At } \\
\text { Time }\end{array}$ & $\begin{array}{r}1 \text { Minute } \\
\text { Later }\end{array}$ & Change \\
\hline 01-Feb-10 & 7:30pm & 0.891 & 0.8911 & $0.0112 \%$ & 1.3924 & 1.3926 & $0.0144 \%$ \\
\hline 01-Mar-10 & $7: 30 \mathrm{pm}$ & 0.8986 & 0.8991 & $0.0556 \%$ & 1.3552 & 1.3555 & $0.0221 \%$ \\
\hline 05-Apr-10 & $8: 30 \mathrm{pm}$ & 0.9179 & 0.9181 & $0.0218 \%$ & 1.3455 & 1.3457 & $0.0149 \%$ \\
\hline 03-May-10 & 8:30pm & 0.9259 & 0.9259 & $0.0000 \%$ & 1.3191 & 1.3191 & $0.0000 \%$ \\
\hline 31-May-10 & 8:30pm & 0.842 & 0.8419 & $-0.0119 \%$ & 1.226 & 1.2257 & $-0.0245 \%$ \\
\hline 05-Jul-10 & $8: 30 \mathrm{pm}$ & 0.8331 & 0.8336 & $0.0600 \%$ & 1.2489 & 1.249 & $-0.0079 \%$ \\
\hline 02-Aug-10 & $8: 30 \mathrm{pm}$ & 0.9127 & 0.9126 & $-0.0110 \%$ & 1.3178 & 1.3177 & $0.0152 \%$ \\
\hline 06-Sep-10 & $8: 30 \mathrm{pm}$ & 0.9139 & 0.9139 & $0.0000 \%$ & 1.2809 & 1.2808 & $-0.0158 \%$ \\
\hline $04-0 c t-10$ & 7:30pm & 0.9667 & 0.9671 & $0.0414 \%$ & 1.3665 & 1.3666 & $0.0429 \%$ \\
\hline
\end{tabular}




\begin{tabular}{|c|c|c|c|c|c|c|c|}
\hline 01-Nov-10 & 7:30pm & 0.9879 & 0.9879 & $0.0000 \%$ & 1.3898 & 1.3897 & $0.0141 \%$ \\
\hline 06-Dec-10 & 7:30pm & 0.9883 & 0.9882 & $-0.0101 \%$ & 1.3287 & 1.3285 & $-0.0151 \%$ \\
\hline 31-Jan-11 & 7:30pm & 0.9983 & 0.9983 & $0.0000 \%$ & 1.3721 & 1.372 & $-0.0147 \%$ \\
\hline 28-Feb-11 & 7:30pm & 1.0187 & 1.0186 & $-0.0098 \%$ & 1.3819 & 1.3818 & $0.0000 \%$ \\
\hline 04-Apr-11 & 8:30pm & 1.0344 & 1.0348 & $0.0387 \%$ & 1.421 & 1.4211 & $0.0140 \%$ \\
\hline 02-May-11 & 8:30pm & 1.0925 & 1.0927 & $0.0183 \%$ & 1.4789 & 1.4789 & $0.0202 \%$ \\
\hline 06-Jun-11 & 8:30pm & 1.073 & 1.0729 & $-0.0093 \%$ & 1.4585 & 1.4584 & $-0.0205 \%$ \\
\hline 04-Jul-11 & 8:30pm & 1.0722 & 1.0725 & $0.0280 \%$ & 1.4524 & 1.4526 & $0.0280 \%$ \\
\hline 01-Aug-11 & 8:30pm & 1.0991 & 1.0989 & $-0.0182 \%$ & 1.4271 & 1.4268 & $-0.0280 \%$ \\
\hline 05-Sep-11 & 8:30pm & 1.0516 & 1.0515 & $-0.0095 \%$ & 1.407 & 1.407 & $0.0142 \%$ \\
\hline 03-Oct-11 & 7:30pm & 0.9504 & 0.9499 & $-0.0526 \%$ & 1.3181 & 1.3179 & $0.0075 \%$ \\
\hline 31-0ct-11 & 7:30pm & 1.0539 & 1.0541 & $0.0190 \%$ & 1.385 & 1.3853 & $0.0000 \%$ \\
\hline 05-Dec-11 & 7:30pm & 1.02523 & 1.02545 & $0.0215 \%$ & 1.33952 & 1.33962 & $-0.0022 \%$ \\
\hline 06-Feb-12 & 7:30pm & 1.07247 & 1.07271 & $0.0224 \%$ & 1.31215 & 1.31225 & $0.0060 \%$ \\
\hline 05-Mar-12 & 7:30pm & 1.06817 & 1.06812 & $-0.0047 \%$ & 1.32207 & 1.32202 & $-0.0287 \%$ \\
\hline 02-Apr-12 & 8:30pm & 1.04227 & 1.04246 & $0.0182 \%$ & 1.33315 & 1.33315 & $0.0000 \%$ \\
\hline 30-Apr-12 & 8:30pm & 1.04225 & 1.0422 & $-0.0048 \%$ & 1.32387 & 1.32389 & $-0.0208 \%$ \\
\hline 04-Jun-12 & 8:30pm & 0.97531 & 0.97532 & $0.0010 \%$ & 1.2537 & 1.25354 & $0.0088 \%$ \\
\hline 02-Jul-12 & 8:30pm & 1.02493 & 1.02477 & $-0.0156 \%$ & 1.25848 & 1.25835 & $0.0032 \%$ \\
\hline 06-Aug-12 & 8:30pm & 1.05547 & 1.05548 & $0.0009 \%$ & 1.23881 & 1.23871 & $0.0106 \%$ \\
\hline 03-Sep-12 & 8:30pm & 1.0231 & 1.02297 & $-0.0127 \%$ & 1.25852 & 1.2585 & $-0.0063 \%$ \\
\hline 01-Oct-12 & 8:30pm & 1.03647 & 1.03634 & $-0.0125 \%$ & 1.28942 & 1.28926 & $-0.0039 \%$ \\
\hline 05-Nov-12 & 7:30pm & 1.03744 & 1.03735 & $-0.0087 \%$ & 1.27962 & 1.27959 & $-0.0236 \%$ \\
\hline 03-Dec-12 & 7:30pm & 1.04207 & 1.0422 & $0.0125 \%$ & 1.30516 & 1.305 & $0.0008 \%$ \\
\hline 04-Feb-13 & 7:30pm & 1.04484 & 1.045 & $0.0153 \%$ & 1.35078 & 1.35078 & $-0.0044 \%$ \\
\hline 04-Mar-13 & 7:30pm & 1.02154 & 1.02132 & $-0.0215 \%$ & 1.30317 & 1.30309 & $-0.0031 \%$ \\
\hline 01-Apr-13 & 7:30pm & 1.04342 & 1.04363 & $0.0201 \%$ & 1.28455 & 1.28458 & $0.0180 \%$ \\
\hline 06-May-13 & 8:30pm & 1.02411 & 1.02415 & $0.0039 \%$ & 1.30708 & 1.30714 & $-0.0296 \%$ \\
\hline 03-Jun-13 & 8:30pm & 0.97509 & 0.97519 & $0.0103 \%$ & 1.30688 & 1.30695 & $0.0054 \%$ \\
\hline 01-Jul-13 & $8: 30 \mathrm{pm}$ & 0.92489 & 0.92469 & $-0.0216 \%$ & 1.30668 & 1.30667 & $-0.0008 \%$ \\
\hline
\end{tabular}

Graph 1 is a historical bar chart which shows the actual changes of Cash Rate as announced by the e Reserve Bank of Australia. Towards the end of 2011, the Cash Rate has been declining and by May 2013, the Reserve Bank has decided to lower the Cash Rate further from $3.00 \%$ to $2.75 \%$. The main decision behind the decrease was that the inflation rate was actually lower than the target and the Reserve Bankof Australia thought that it would help increase employment and economic growth in Australia since it was a little below the growth trend (Stevens, 2013). 
Graph 01: Cash rate (2010-2013)

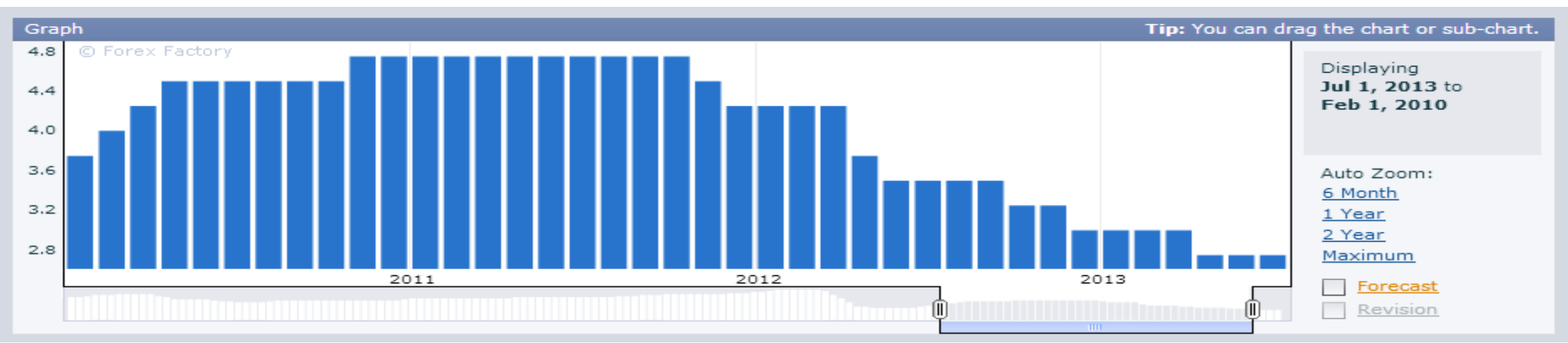

Source: Forexfactory (2014)

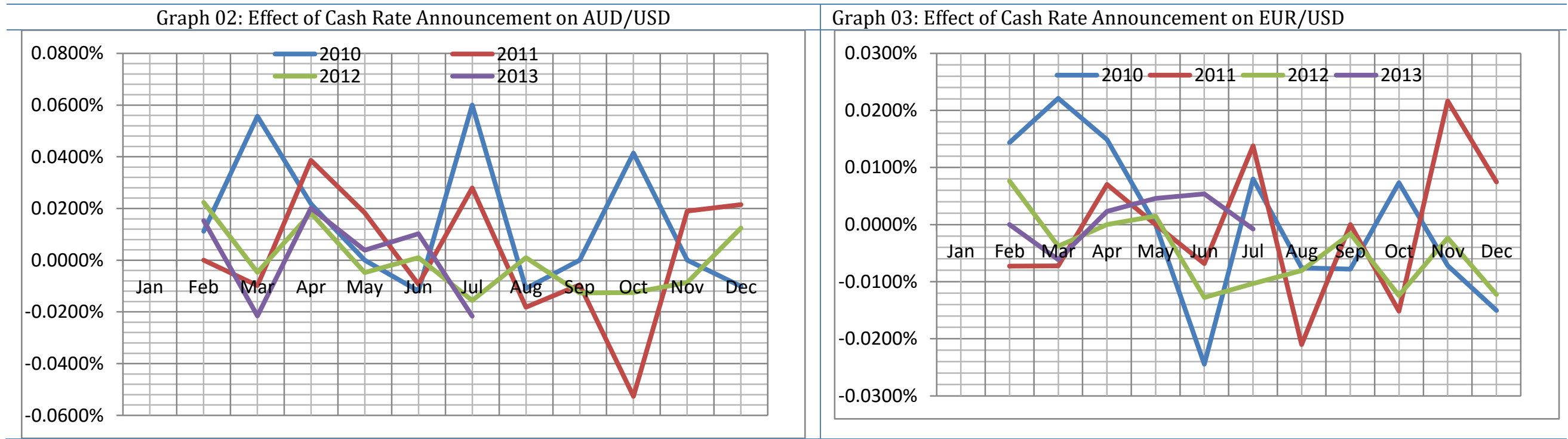

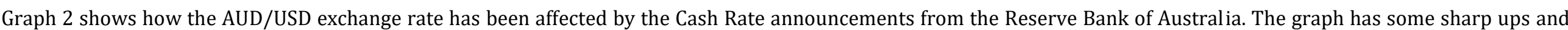

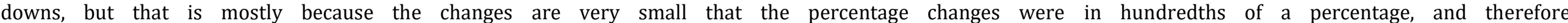


the graph had to be magnified to see the actual reaction of the market, or the affects that the announcements had on the market. Since the percentage change hovers in the range of $\pm 0.06 \%$, it is safe to say that the exchange rate is not significantly affected by the announcements. In line with Graph 1 which shows how the Cash Rate announcements have changed over time, and even with the Cash Rates going lower since the end of 2011, it seems to not have an effect on the exchange rate. This is in line with Gurrib (2010) where the effects of news announcements tend to decay over time. While, graph 3 shows that there are minute fluctuations in the EUR/USD exchange rate. It is not critical to know whether or not the Cash Rate announcements have contributed to the percentage changes, because the changes are so small such that they can be attributed to a normal trading day without announcements.

\subsection{Minimum bid rate announcements}

Minimum Bid Rate is the main refinancing rate, which is the publicly visible interest rate that the European Central Bank announces.

Table 02: AUD and EUR 1 minute data post release of minimum bid rate announcement

\begin{tabular}{|c|c|c|c|c|c|c|c|}
\hline & & AUD & AUD & AUD & EUR & EUR & EUR \\
\hline Date & $\begin{array}{r}\text { Time of } \\
\text { Announcement }\end{array}$ & At Time & $\begin{array}{r}1 \text { Minute } \\
\text { Later }\end{array}$ & Change & At Time & $\begin{array}{r}1 \text { Minute } \\
\text { Later }\end{array}$ & Change \\
\hline 14 January 2010 & $4: 45 \mathrm{AM}$ & 0.93 & 0.9299 & $-0.0108 \%$ & 1.4522 & 1.4519 & $-0.0207 \%$ \\
\hline 04 February 2010 & 4.45AM & 0.8792 & 0.8793 & $0.0114 \%$ & 1.3845 & 1.3844 & $-0.0072 \%$ \\
\hline 03 April 2010 & 4.45AM & 0.8997 & 0.8997 & $0.0000 \%$ & 1.3653 & 1.3651 & $-0.0146 \%$ \\
\hline 08 April 2010 & $3.45 \mathrm{AM}$ & 0.9241 & 0.9239 & $-0.0216 \%$ & 1.3309 & 1.3297 & $-0.0902 \%$ \\
\hline 06 May 2010 & 3.45AM & 0.9037 & 0.9039 & $0.0221 \%$ & 1.2786 & 1.2789 & $0.0235 \%$ \\
\hline 10 June 2010 & $3.45 \mathrm{AM}$ & 0.838 & 0.8378 & $-0.0239 \%$ & 1.2032 & 1.2029 & $-0.0249 \%$ \\
\hline 08 July 2010 & $3.45 \mathrm{AM}$ & 0.8731 & 0.873 & $-0.0115 \%$ & 1.2641 & 1.2642 & $0.0316 \%$ \\
\hline 05 August 2010 & $3.45 \mathrm{AM}$ & 0.9144 & 0.9145 & $0.0109 \%$ & 1.3141 & 1.3142 & $0.0000 \%$ \\
\hline 02 September 2010 & 3.45AM & 0.9059 & 0.9062 & $0.0331 \%$ & 1.2782 & 1.2784 & $-0.0312 \%$ \\
\hline 07 October 2010 & 3.45AM & 0.9897 & 0.9896 & $-0.0101 \%$ & 1.3987 & 1.3989 & $-0.0072 \%$ \\
\hline 04 November 2010 & 4.45AM & 1.0081 & 1.008 & $-0.0099 \%$ & 1.4202 & 1.4202 & $-0.0070 \%$ \\
\hline 02 December 2010 & 4.45AM & 0.9688 & 0.9685 & $-0.0310 \%$ & 1.3184 & 1.3184 & $-0.0227 \%$ \\
\hline 13 January 2011 & 4.45AM & 0.9962 & 0.9963 & $0.0100 \%$ & 1.3157 & 1.3157 & $0.0076 \%$ \\
\hline 03 February 2011 & 4.45AM & 1.0136 & 1.0138 & $0.0197 \%$ & 1.378 & 1.3785 & $0.0073 \%$ \\
\hline 03 March 2011 & 4.45AM & 1.0161 & 1.0163 & $0.0197 \%$ & 1.3847 & 1.3848 & $0.0000 \%$ \\
\hline 07 April 2011 & $3.45 \mathrm{AM}$ & 1.048 & 1.048 & $0.0000 \%$ & 1.429 & 1.4288 & $0.0070 \%$ \\
\hline 05 May 2011 & $3.45 \mathrm{AM}$ & 1.0717 & 1.0715 & $-0.0187 \%$ & 1.489 & 1.489 & $-0.0134 \%$ \\
\hline 09 June 2011 & $3.45 \mathrm{AM}$ & 1.0603 & 1.0602 & $-0.0094 \%$ & 1.4641 & 1.4638 & $-0.0205 \%$ \\
\hline 05 July 2011 & 3.45AM & 1.0689 & 1.0687 & $-0.0187 \%$ & 1.4478 & 1.4485 & $0.0419 \%$ \\
\hline 04 August 2011 & $3.45 \mathrm{AM}$ & 1.0657 & 1.0656 & $-0.0094 \%$ & 1.4314 & 1.4316 & $0.0000 \%$ \\
\hline 08 September 2011 & $3.45 \mathrm{AM}$ & 1.058 & 1.0582 & $0.0189 \%$ & 1.3888 & 1.3886 & $-0.0142 \%$ \\
\hline 06 October 2011 & $3.45 \mathrm{AM}$ & 0.9531 & 0.9535 & $0.0420 \%$ & 1.3343 & 1.3339 & $0.0000 \%$ \\
\hline 03 November 2011 & 4.45AM & 1.0239 & 1.0243 & $0.0391 \%$ & 1.3681 & 1.3679 & $0.0146 \%$ \\
\hline 08 December 2011 & $4.45 \mathrm{AM}$ & 1.02857 & 1.02838 & $-0.0185 \%$ & 1.34058 & 1.34018 & $0.0097 \%$ \\
\hline 12 January 2012 & 4.45AM & 1.03098 & 1.03097 & $-0.0010 \%$ & 1.27261 & 1.27248 & $-0.0157 \%$ \\
\hline 09 February 2012 & 4.45AM & 1.08225 & 1.0822 & $-0.0046 \%$ & 1.32972 & 1.32946 & $-0.0128 \%$ \\
\hline 08 March 2012 & 4.45AM & 1.06498 & 1.06523 & $0.0235 \%$ & 1.3276 & 1.32763 & $-0.0098 \%$ \\
\hline 04 April 2013 & $3.45 \mathrm{AM}$ & 1.02554 & 1.02552 & $-0.0020 \%$ & 1.31947 & 1.31948 & $0.0008 \%$ \\
\hline 03 May 2012 & $3.45 \mathrm{AM}$ & 1.03001 & 1.02999 & $-0.0019 \%$ & 1.31525 & 1.3155 & $-0.0327 \%$ \\
\hline 06 June 2012 & 3.45AM & 0.9851 & 0.98555 & $0.0457 \%$ & 1.25052 & 1.25084 & $-0.0016 \%$ \\
\hline 05 July 2012 & $3.45 \mathrm{AM}$ & 1.02633 & 1.02641 & $0.0078 \%$ & 1.25226 & 1.25257 & $-0.0216 \%$ \\
\hline 02 August 2012 & $3.45 \mathrm{AM}$ & 1.05515 & 1.0553 & $0.0142 \%$ & 1.21957 & 1.21974 & $0.0310 \%$ \\
\hline 06 September 2012 & $3.45 \mathrm{AM}$ & 1.01824 & 1.01825 & $0.0010 \%$ & 1.26102 & 1.26125 & $-0.0135 \%$ \\
\hline 04 October 2012 & $3.45 \mathrm{AM}$ & 1.02208 & 1.02202 & $-0.0059 \%$ & 1.29427 & 1.29434 & $0.0247 \%$ \\
\hline 08 November 2012 & 4.45AM & 1.0401 & 1.03985 & $-0.0240 \%$ & 1.27318 & 1.27309 & $-0.0039 \%$ \\
\hline 06 December 2012 & $4.45 \mathrm{AM}$ & 1.04863 & 1.04848 & $-0.0143 \%$ & 1.30767 & 1.30755 & $-0.0069 \%$ \\
\hline 10 January 2013 & 4.45AM & 1.0569 & 1.05714 & $0.0227 \%$ & 1.30778 & 1.30851 & $-0.0214 \%$ \\
\hline 07 February 2013 & 4.45AM & 1.03252 & 1.03243 & $-0.0087 \%$ & 1.3565 & 1.35685 & $-0.0007 \%$ \\
\hline 07 March 2013 & 4.45AM & 1.02664 & 1.02665 & $0.0010 \%$ & 1.30397 & 1.30385 & $-0.0092 \%$ \\
\hline 04 April 2013 & $3.45 \mathrm{AM}$ & 1.04152 & 1.04176 & $0.0230 \%$ & 1.28184 & 1.28205 & $0.0188 \%$ \\
\hline 02 May 2013 & $3.45 \mathrm{AM}$ & 1.02324 & 1.02337 & $0.0127 \%$ & 1.31556 & 1.31564 & $0.0076 \%$ \\
\hline 06 June 2013 & $3.45 \mathrm{AM}$ & 0.9478 & 0.94784 & $0.0042 \%$ & 1.31201 & 1.31192 & $-0.0069 \%$ \\
\hline 04 July 2013 & $3.45 \mathrm{AM}$ & 0.91355 & 0.91373 & $0.0197 \%$ & 1.30024 & 1.30041 & $0.0131 \%$ \\
\hline
\end{tabular}




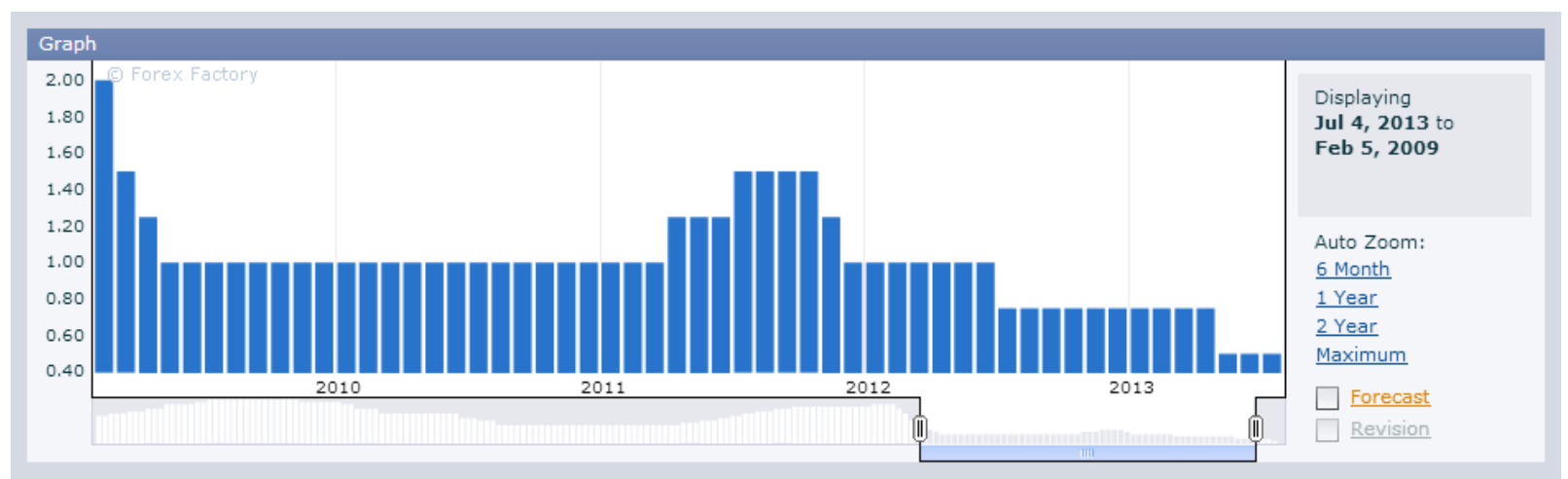

Source: Forexfactory (2014)
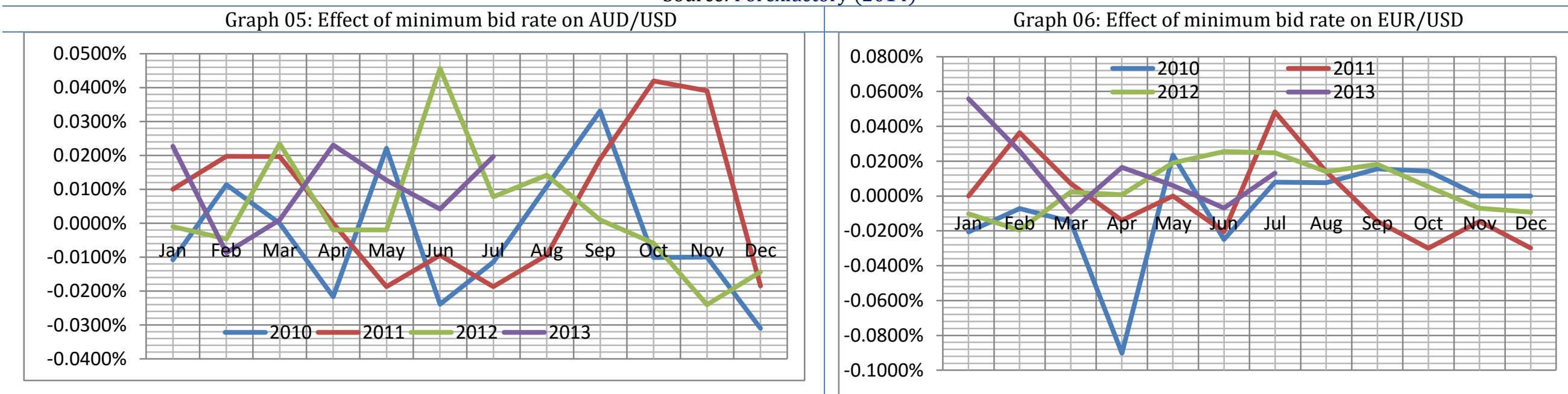

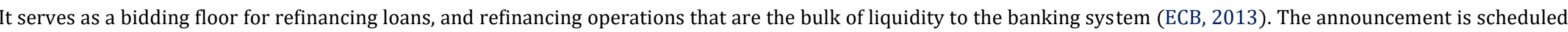

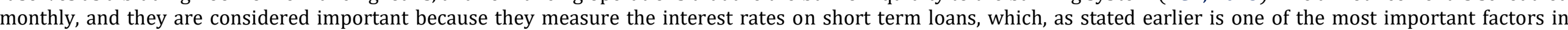

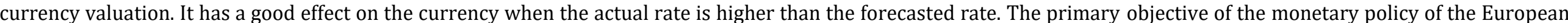

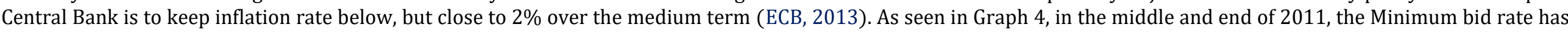

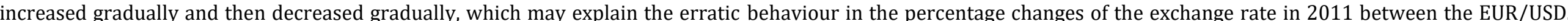

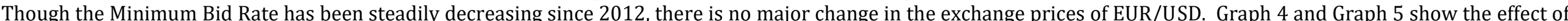
the Minimum Bid Rate announcements on the financial markets and the exchange rates of AUD/USD and EUR/USD respectively. 
Graph 5 shows the percentage changes of the AUD/USD exchange rate with the announcements of the European Central Bank regarding the Minimum Bid Rate and the graph does not show any signs of significant change with the exchange rate fluctuating within the general range of $\pm 0.03 \%$. A small anomaly shows that the exchange rate has increased by $0.04 \%$ in June 2012, even though the Minimum Bid Rate has remained unchanged from May 2012, therefore, there might have been another announcement that has affected the exchange rate which is not reported here. Although it is still not significant, the percentage change in exchange rate was less than $0.01 \%$ in July, which is when the European Central Bank has decided to decrease the Minimum Bid Rate from $1 \%$ to $0.75 \%$, as gathered in graph 4.

Graph 6 shows the percentage changes of the exchange rate of EUR/USD. Clearly, there is an anomaly in April 2010 where the exchange rate changed by around $-0.09 \%$.Further, findings shows no changes in the Minimum Bid Rate all year in 2010, which may mean that there are other announcements that have affected the currency and created the dip in the exchange rate, especially since the majority of the percentage changes have taken place in the range of $\pm 0.03 \%$.

\subsection{Official bank rate}

Official Bank Rate, also known as Bank of England Base Rate, is the interest rate that the Bank of England charges banks for secured overnight lending. It is the British Government's key interest rate for enacting monetary policy. The announcements are scheduled monthly and they are important because they are related to the short term interest rates which tend to be one of those factors affecting currency valuation. It is generally better for the home currency (GBP) when the actual rate is higher than the forecasted rate.

Table 03: AUD and EUR 1 minute data post release of the official bank rate announcement

\begin{tabular}{|c|c|c|c|c|c|c|c|}
\hline & & AUD & AUD & AUD & EUR & EUR & EUR \\
\hline Date & $\begin{array}{l}\text { Time of } \\
\text { Announcement }\end{array}$ & $\begin{array}{l}\text { At } \\
\text { Time }\end{array}$ & $\begin{array}{l}1 \text { Minute } \\
\text { Later }\end{array}$ & Change & $\begin{array}{l}\text { At } \\
\text { Time }\end{array}$ & $\begin{array}{l}1 \text { Minute } \\
\text { Later }\end{array}$ & Change \\
\hline 07 January 2010 & 5:00am & 0.9196 & 0.9197 & $0.0109 \%$ & 1.4353 & 1.4357 & $0.0279 \%$ \\
\hline 04 February 2010 & 5:00am & 0.8794 & 0.879 & $-0.0455 \%$ & 1.3847 & 1.3845 & $-0.0144 \%$ \\
\hline 04 March 2010 & 5:00am & 0.9005 & 0.9006 & $0.0111 \%$ & 1.3648 & 1.3648 & $0.0000 \%$ \\
\hline 08 April 2010 & 4:00am & 0.926 & 0.9263 & $0.0324 \%$ & 1.3288 & 1.3293 & $0.0376 \%$ \\
\hline 10 May 2010 & 4:00am & 0.9045 & 0.9043 & $-0.0221 \%$ & 1.304 & 1.3039 & $-0.0077 \%$ \\
\hline 10 June 2010 & 4:00am & 0.8374 & 0.8385 & $0.1312 \%$ & 1.2012 & 1.2014 & $0.0167 \%$ \\
\hline 08 July 2010 & 4:00am & 0.8739 & 0.8736 & $-0.0343 \%$ & 1.2648 & 1.2647 & $-0.0079 \%$ \\
\hline 05 August 2010 & 4:00am & 0.914 & 0.9141 & $0.0109 \%$ & 1.3151 & 1.3153 & $0.0152 \%$ \\
\hline 09 September 2010 & 4:00am & 0.9228 & 0.9228 & $0.0000 \%$ & 1.2679 & 1.2677 & $-0.0158 \%$ \\
\hline 07 October 2010 & 4:00am & 0.9905 & 0.9908 & $0.0303 \%$ & 1.3982 & 1.3988 & $0.0429 \%$ \\
\hline 04 November 2010 & 5:00am & 1.0085 & 1.0087 & $0.0198 \%$ & 1.4206 & 1.4208 & $0.0141 \%$ \\
\hline 09 December 2010 & 5:00am & 0.9841 & 0.9837 & $-0.0407 \%$ & 1.3213 & 1.3211 & $-0.0151 \%$ \\
\hline 13 January 2011 & 5:00am & 0.9962 & 0.9961 & $-0.0100 \%$ & 1.3152 & 1.3147 & $-0.0380 \%$ \\
\hline 10 February 2011 & 5:00am & 1.003 & 1.0032 & 0.0199\% & 1.363 & 1.3628 & $-0.0147 \%$ \\
\hline 10 March 2011 & 5:00am & 1.0038 & 1.0038 & $0.0000 \%$ & 1.3835 & 1.3835 & $0.0000 \%$ \\
\hline 07 April 2011 & 4:00am & 1.0479 & 1.048 & $0.0095 \%$ & 1.4278 & 1.428 & $0.0140 \%$ \\
\hline 05 May 2011 & 4:00am & 1.0722 & 1.072 & $-0.0187 \%$ & 1.4879 & 1.4882 & $0.0202 \%$ \\
\hline 09 June 2011 & 4:00am & $00: 52.8$ & $01: 58.4$ & $0.0000 \%$ & 1.4628 & 1.4625 & $-0.0205 \%$ \\
\hline 07 July 2011 & 4:00am & 1.0736 & 1.0739 & $0.0279 \%$ & 1.4298 & 1.4302 & $0.0280 \%$ \\
\hline 04 August 2011 & 4:00am & 1.065 & 1.065 & $0.0000 \%$ & 1.4264 & 1.426 & $-0.0280 \%$ \\
\hline 06 October 2011 & 4:00am & 0.971 & 0.9712 & $0.0206 \%$ & 1.4109 & 1.4107 & $-0.0142 \%$ \\
\hline 10 November 2011 & 5:00am & 1.015 & 1.0148 & $-0.0197 \%$ & 1.3346 & 1.3347 & $0.0075 \%$ \\
\hline 08 December 2011 & 5:00am & 1.02909 & 1.02903 & $-0.0058 \%$ & 1.3616 & 1.3616 & $0.0000 \%$ \\
\hline 12 January 2012 & 5:00am & 1.03298 & 1.03292 & $-0.0058 \%$ & 1.34025 & 1.34022 & $-0.0022 \%$ \\
\hline 09 February 2012 & 5:00am & 1.08311 & 1.08333 & $0.0203 \%$ & 1.27511 & 1.27484 & $-0.0212 \%$ \\
\hline 08 March 2012 & 5:00am & 1.06448 & 1.06435 & $-0.0122 \%$ & 1.32714 & 1.32722 & $0.0060 \%$ \\
\hline 05 April 2012 & 4:00am & 1.26058 & 1.26056 & $-0.0016 \%$ & 1.32198 & 1.3216 & $-0.0287 \%$ \\
\hline
\end{tabular}




\begin{tabular}{|c|c|c|c|c|c|c|c|}
\hline 10 May 2012 & 4:00am & 1.01107 & 1.0108 & $-0.0267 \%$ & 1.31467 & 1.31449 & $-0.0137 \%$ \\
\hline 07 June 2012 & 4:00am & 0.99375 & 0.99387 & $0.0121 \%$ & 1.29587 & 1.2956 & $-0.0208 \%$ \\
\hline 05 July 2012 & 4:00am & 1.02632 & 1.02636 & $0.0039 \%$ & 1.2546 & 1.25471 & $0.0088 \%$ \\
\hline 02 August 2012 & 4:00am & 1.04835 & 1.04854 & $0.0181 \%$ & 1.25229 & 1.25233 & $0.0032 \%$ \\
\hline 06 September 2012 & 4:00am & 1.0243 & 1.02422 & $-0.0078 \%$ & 1.226 & 1.22613 & $0.0106 \%$ \\
\hline 04 October 2012 & 4:00am & 1.02227 & 1.02225 & $-0.0020 \%$ & 1.26199 & 1.26191 & $-0.0063 \%$ \\
\hline 08 November 2012 & 5:00am & 1.0399 & 1.03986 & $-0.0038 \%$ & 1.29464 & 1.29459 & $-0.0039 \%$ \\
\hline 06 December 2012 & 5:00am & 1.04861 & 1.04874 & $0.0124 \%$ & 1.27326 & 1.27296 & $-0.0236 \%$ \\
\hline 10 January 2013 & 5:00am & 1.05757 & 1.05756 & $-0.0009 \%$ & 1.30777 & 1.30778 & $0.0008 \%$ \\
\hline 07 February 2013 & 5:00am & 1.03253 & 1.0325 & $-0.0029 \%$ & 1.31035 & 1.31035 & $0.0000 \%$ \\
\hline 07 March 2013 & 5:00am & 1.02657 & 1.02658 & $0.0010 \%$ & 1.35631 & 1.35625 & $-0.0044 \%$ \\
\hline 04 April 2013 & 4:00am & 1.0411 & 1.04103 & $-0.0067 \%$ & 1.30414 & 1.3041 & $-0.0031 \%$ \\
\hline 09 May 2013 & 4:00am & 1.02344 & 1.02324 & $-0.0195 \%$ & 1.27857 & 1.2788 & $0.0180 \%$ \\
\hline 06 June 2013 & 4:00am & 0.9488 & 0.94916 & $0.0379 \%$ & 1.31667 & 1.31628 & $-0.0296 \%$ \\
\hline 04 July 2013 & 4:00am & 0.91012 & 0.91014 & $0.0022 \%$ & 1.31177 & 1.31209 & $0.0244 \%$ \\
\hline
\end{tabular}

Graph 7 shows that the Official Bank Rate as announced by the Bank of England has not changed from 0.5\% since at least January 2010, but once the data set is extended further back in time, it will show that in fact, the Official Bank Rate has not changed since March 2009. Graph 8 and Graph 9 show the effect of the Official Bank Rate announcements on the financial markets and the exchange rates of AUD/USD and EUR/USD respectively.

Graph 8 shows that the Official Bank Rate as announced by the Bank of England does not have a big impact on the percentage change of the exchange rate of AUD/USD, because the graph shows that the changes are within the range of $\pm 0.03 \%$, except in June 2010 , where the change of exchange rate suddenly spiked to around $0.13 \%$. Graph 9 shows that the Official Bank Rate has been steady at $0.5 \%$ for the whole period, which suggests that there may have been an announcement that has inflicted the change that was not related to Central Bank announcements of the currencies that have been chosen for this paper. $0.13 \%$ is not a significant change, but when compared to the other percentage changes, it seems to be higher than earlier findings.

Even though Graph 9 shows sharper spikes and dips with the changes in the exchange rate of EUR/USD than with the AUD/USD, it is important to notice that Graph 8 range is between $\pm 0.05 \%$, while for the AUD/USD the graph range was between $-0.06 \%$ and $0.16 \%$, which made it look smoother, but once the anomaly is covered, it will be clear that the spikes and dips are similar to that of the percentage change of the EUR/USD exchange rate.

\subsection{Comparative analysis}

Graph 10 provides an overview of all the three announcements and how they have affected the exchange rate of AUD/USD with time, beginning in January 2010 and ending in July 2013. It is clear from the graph that almost all the percentage changes in the exchange rate have been within the $\pm 0.05 \%$ range, which are not significant changes, except for the $0.13 \%$ change in June 2010 with the Official Bank Rate announcement affecting the exchange rate, even though $0.13 \%$ is not a significant change, but it remains higher than the other results reported here. The highest negative percentage change of exchange rate was with the Cash Rate announcement that took place on October 2011 by the Reserve Bank of Australia. Breaks are due to the non- release of one of the three announcements during a specific time period. 


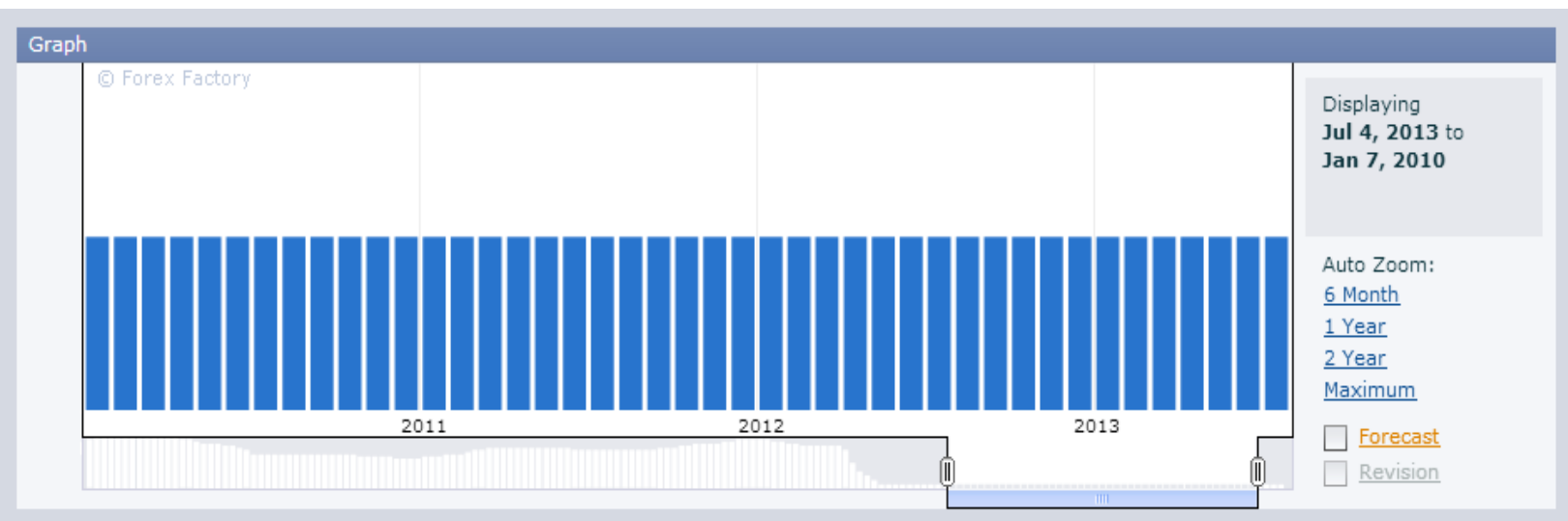

Source: Forexfactory (2014)

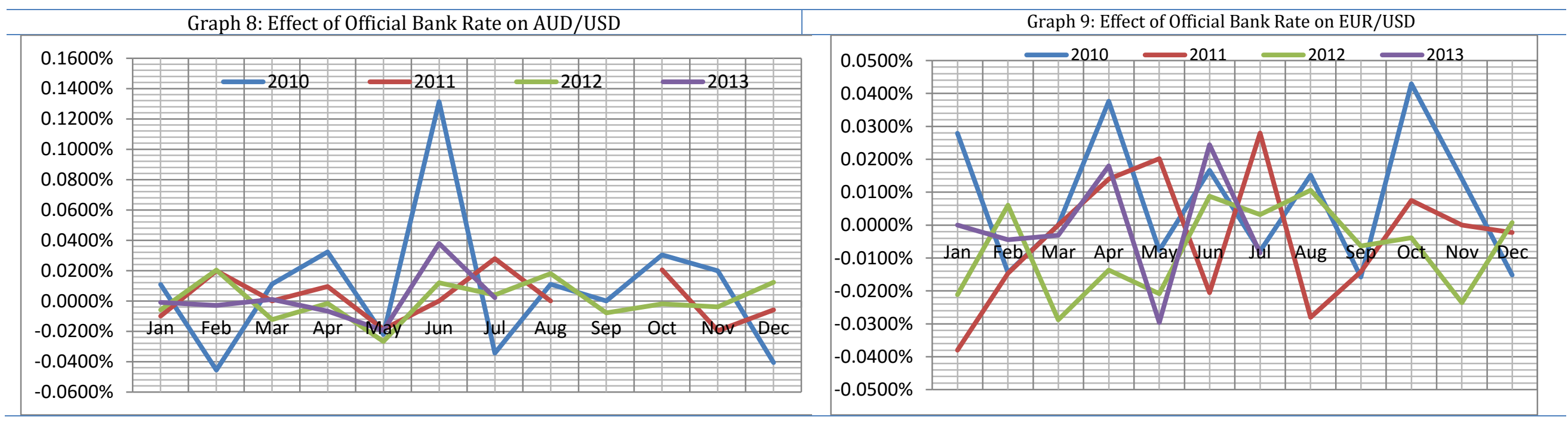

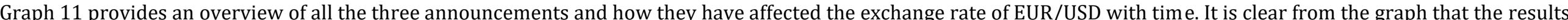

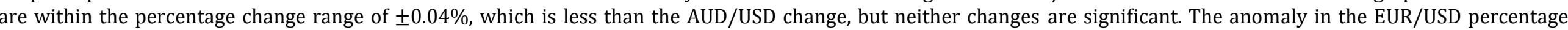

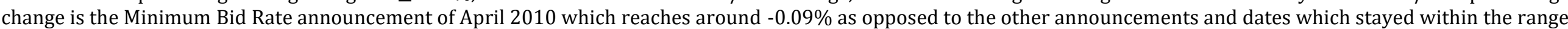
of $\pm 0.04 \%$. 
Graph 10: Effects of the Cash Rate, Minimum Bid Rate and Official Bank Rate on the AUD/USD

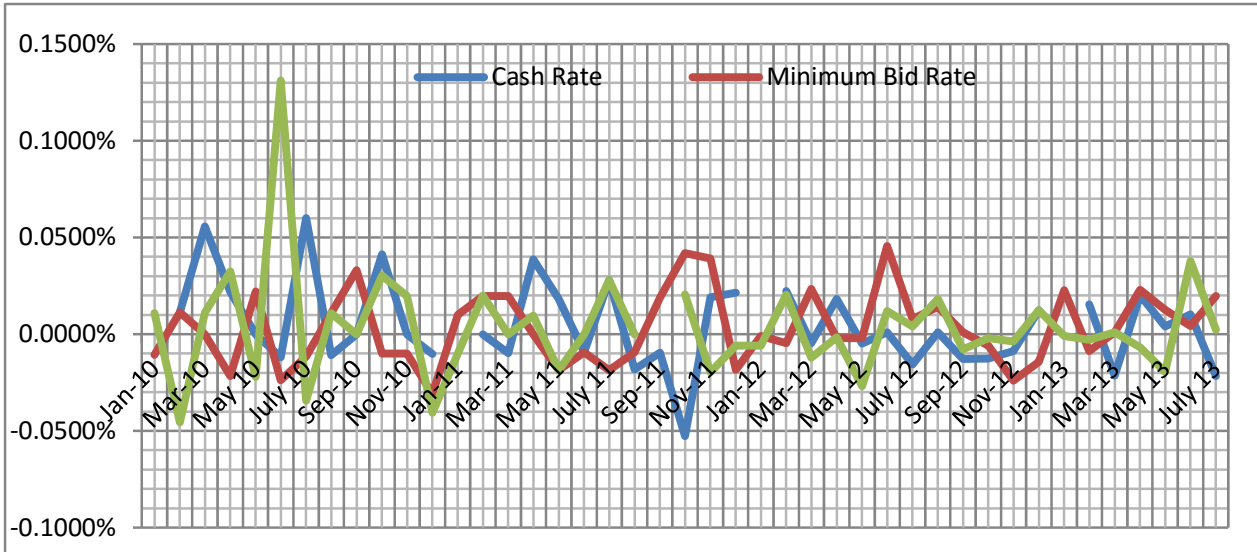

Graph 12: Average yearly percentage change in AUD/USD following announcements' releases

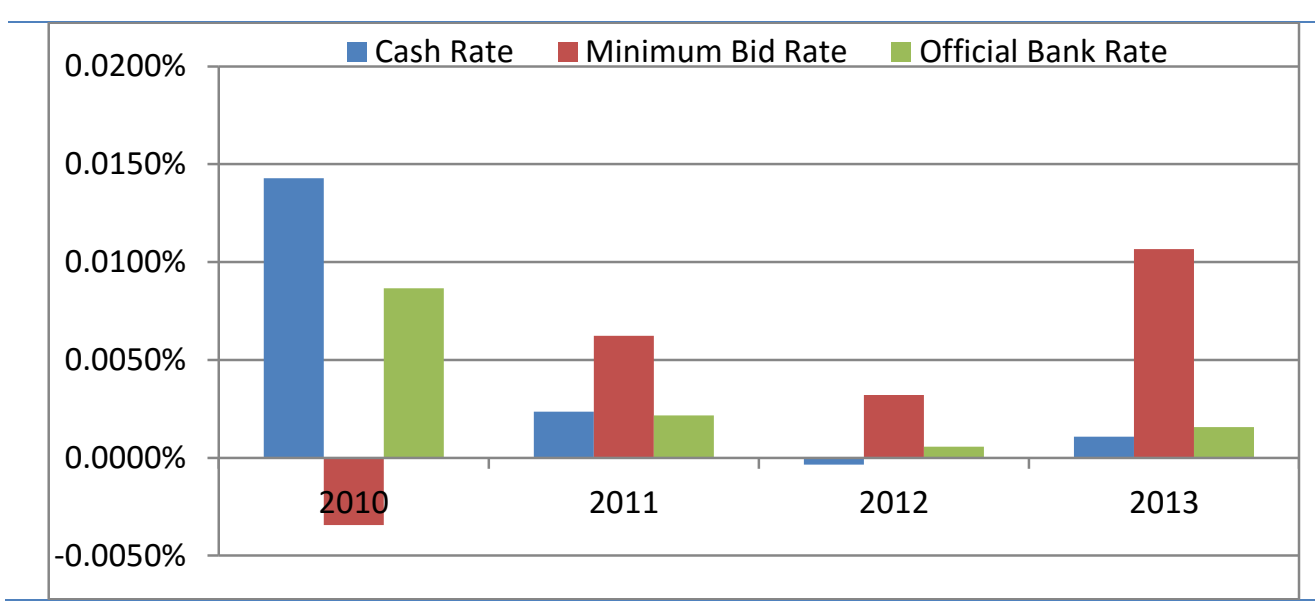

Graph 11: Effects of the Cash Rate, Minimum Bid Rate and Official Bank Rate on the EUR/USD
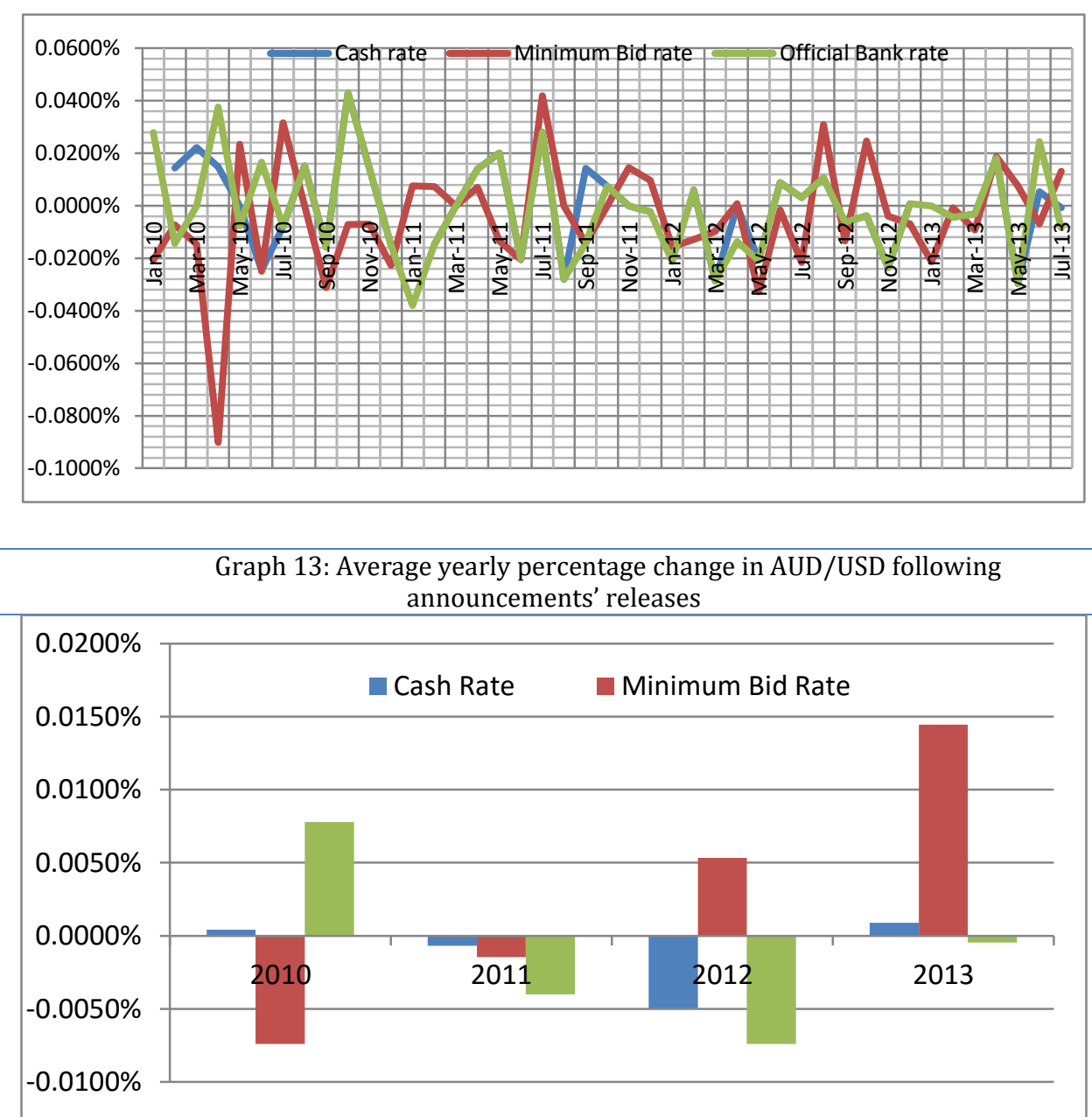
Breaks are due to the non- release of one of the three announcements during a specific time period. Due to the existence of those breaks, the comparison of the effect of the three announcements on the exchange rate becomes less obvious. An average yearly percentage change in the currency pairs is used to smooth out any possible break in the years. Graphs 12 and 13 provide the results on the AUD/USD and EUR/USD respectively.

From Graph 12, it is noticeable that the only announcements that have had an average positive change in exchange rates are those of the Official Bank Rate. The Minimum Bid Rate has had a negative average percentage change in AUD/USD exchange rates but has stayed positive since, even though all these changes are of minute significance with the highest average change having been around $0.014 \%$. The highest negative percentage change of exchange rate was with the Minimum Bid Rate announcement that took place on April 2011 by the European Central Bank, while the highest positive percentage change of exchange rate was with the Official Bank Rate announcement in October 2010.

Graph 13 shows the average yearly percentage changes in the EUR/USD exchange rate. It is noteworthy to point out that there seems to have more negative average percentage changes than positive average percentage changes. The highest percentage change is around $0.0144 \%$. The highest negative percentage change was around $0.007 \%$ as opposed to the highest negative percentage change of around $0.003 \%$ for the AUD/USD. Findings tend to support that currencies are more affected by the announcements made by their respective monetary authorities.

\subsection{Robustness testing}

A look at the change in both the AUD and EURO against the USD following cash rate announcements, show that there is some displacement in the dataset for the period ending 10/03/2011. To robust test earlier findings, the CUSUM (Cumulative Sum Control Chart) structural test is applied to test for the constancy of coefficients between the currency pairs' change and news announcements. The test is carried out both on the effect of the change in EUR/USD against the effect of the change in AUD/USD following the cash rate announcement. Essentially, the CUSUM test takes the cumulative sum of recursive residuals and plots its value against the upper [K, $\pm 3 \mathrm{a}(\mathrm{T}-\mathrm{k}) 1 / 2]$ and lower $[\mathrm{K}, \pm \mathrm{a}(\mathrm{T}-\mathrm{k}) 1 / 2]$ bounds of the $95 \%$ confidence interval at each point, ( $\mathrm{a}=0.948$ for $95 \%$ level) as per Page (1954) and (Brown, Durbin, and Evans, 1975).The CUSUM test is based on the statistic as follows:

$$
W_{t}{ }^{\mathrm{n}}=\sum_{n=k+1}^{t} \frac{\lambda_{n}}{\sigma}
$$

for $t=n+1, \ldots, T$, where $\lambda$ is the recursive residual, and $\sigma$ is the standard deviation of the recursive residuals $\lambda_{n}$. If the $\beta$ vector remains constant from period to period, $E\left(W_{t}\right)=0$. If, however, the $\beta$ coefficient changes within the data period, $W_{t}$ will tend to diverge from the zero mean value line.

Table 4: Chow structural break test

F test of no structural break:

Effect of EURO/USD on

AUD/USD Change

0.2826

Effect of AUD/USD on EUR/USD

Change

The findings are reported in Graph 14. It can be observed that after the 10/03/2011 period, the parameters in both CUSUM graphs become more unstable, although not breaking the $5 \%$ significance level. To check for the statistical validity of the instability between the variables' relationships, the Chow test is used to check for any significant structural break in the models. As reported in Table 4, the low probabilities of 0.2826 and 0.2210 suggest there are no structural break at the $10 / 03 / 2011$ period. 
Graph 14: Stability diagnostic test of the recursive residuals

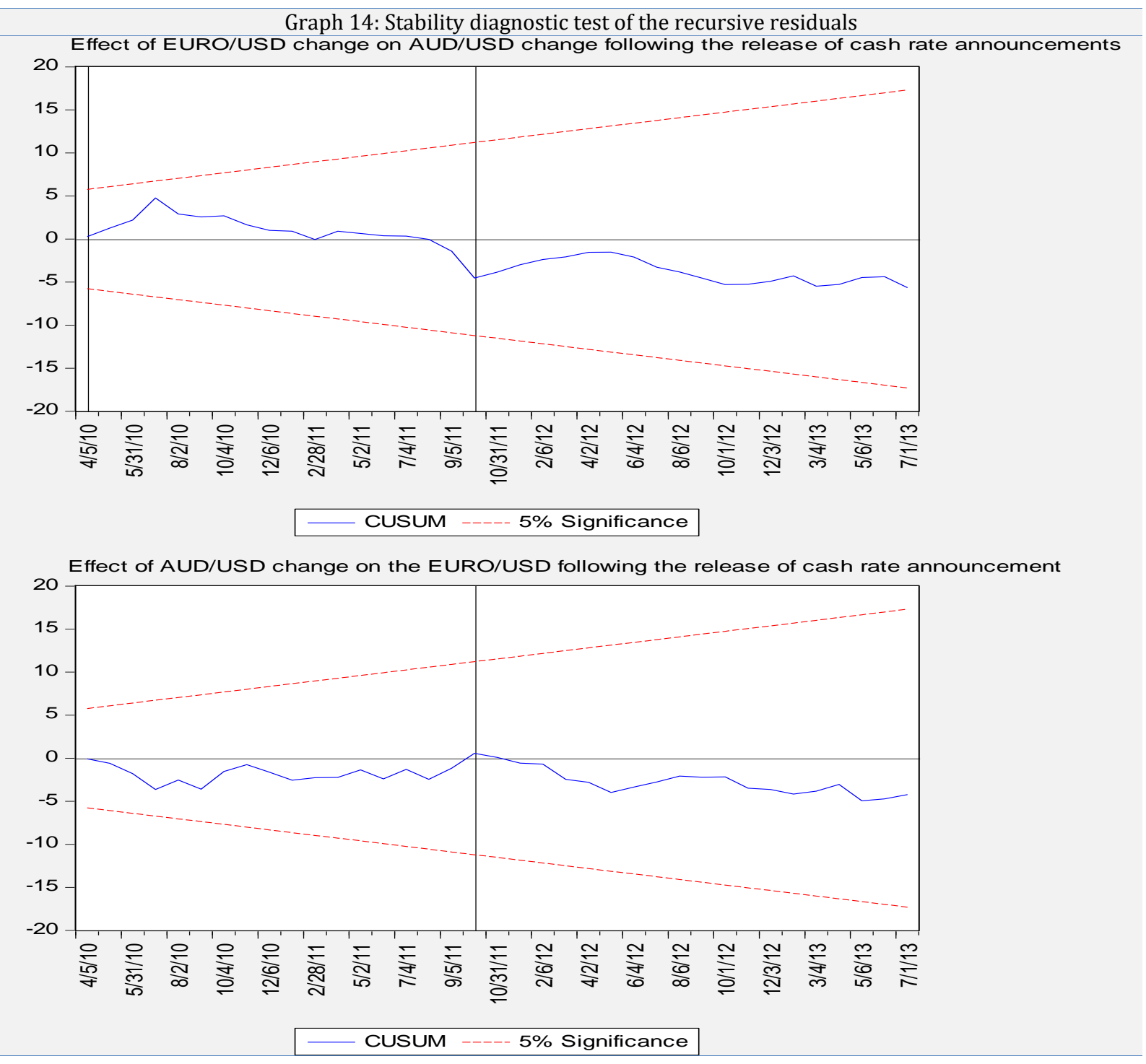

\subsection{Conclusion}

Findings tend to support that announcements made by the respective monetary authorities do not have a significant role in the percentage changes of the exchange rate. For a profit of one Australian Dollar on the 0.014\% change in the currency exchange rate of the AUD/USD, a trader would have to sell 7,142 Australian Dollars, which may not be worthwhile for many traders and even in huge quantities, it would not be worthwhile for traders since there are transaction costs along with the purchase of sale of the currencies. There are many other factors that affect the exchange rates between currencies, some of them are apparent and measureable, while the others may seem like invisible forces that might have effects that are not accurately foreseeable, but are still measureable once they occur, such as Terms of Trade, Current Account Deficit, Public Debt, the Economic and Political Stability, Rate of Employment, Rate of Unemployment, Inflation Rate, Gross National Product, Gross Domestic Product. Future areas of research can include other currencies' comparative analysis. The Pound Sterling is the fourth more traded currency around the globe after the United States Dollar, the Euro, and the Japanese Yen. Structural breaks were tested for at some specific data period, but found no significant breakpoint to justify for the possibility of inadequate model constructions. It would be interesting to look at the currency market reactions to the announcements made by Bank of Japanand analyse how the exchange rates are affected by them. There could have been more than one announcement that was not from the Central Bank that occurred at the same time of the Central Bank announcements that affected the exchange rate, but they were not taken into consideration for analytical purposes. The gap between the time of announcement and the measurement of the value was taken at one minute after the announcement in comparison with the exchange rate at the time of the announcement to keep the results in a controlled environment, but perhaps expanding the gap between the announcement and the measurement (5-10 minutes) could help form a better view of the reaction of the financial market to the announcements made. The policy implication of this study is that findings tend to suggest that regulatory bodies such as SEC and CFTC need to revisit their stance regarding High Frequency Trading systems and all their regulatory tools such as the pause rules and the consolidated audit trails (CAT). The insignificance of one minute 
effect of global news over the most volatile financial markets (foreign currency markets) needs however not to be overlooked. Market Higher frequency data is definitely an area of future research to be remembered and dealt with.

\section{References}

Agenor, P. R., \& Pereira da Silva, L. A., 2012. Macroeconomic stability, financial stability, and monetary policy rules. International Finance, 15: 205-224. http://dx.doi.org/10.1111/j.1468-2362.2012.01302.x

Andersen, T. G., 2000. Some reflections on analysis of high-frequency data. Journal of Business and Economic Statistics, 18(2): 146-153. http://dx.doi.org/10.2307/1392552

BIS. 2013. Triennial central bank survey, Bank of International Settlements. http://www.bis.org/publ/rpfx13.htm [Accessed on 01/02/2014]

Brown, R. L., J. Durbin, and J. M. Evans., 1975. Techniques for testing the constancy of regression relationships over time, Journal of the Royal Statistical Society, Series B, 37: 149-192.

Darskuviene, V., 2010. Financial markets. Leonardo da Vinci programme project. http://www.bcci.bg/projects/latvia/pdf/7_Financial_markets.pdf [Accessed 10/04/2014]

ECB.2013. Key ECB interest rates, European Central Bank. http://www.ecb.europa.eu/stats/monetary/rates/html/index.en.html [Accessed on 02/02/2014]

Forexfactory. 2014. Forex Factory. http://www.forexfactory.com/ [Accessed on 08/15/2013]

Gouriéroux, C. and Jasiak, J., 2001. Financial econometrics: Problems, Models and Methods. New Jersey: Princeton University Press.

Gurrib, I., 2008. Do large hedgers and speculators react to events? a stability and events analysis. Applied Financial Economics Letters, 4 (4): 259-267. http://dx.doi.org/10.1080/17446540701720501

Gurrib, I., 2010. Measuring risk for large hedgers and large speculators in major US futures markets. The Journal of Risk, 12(2): 79-103.

Laïdi, A., 2008. Currency trading and intermarket analysis: how to profit from the shifting currents in blobal markets. John Wiley \& Sons.

Lin, Tom C. W.2013. The new investor, 60 UCLA Law Review 678, Temple University Legal Studies Research Paper No. 2013-45

Page, E. S., 1954.Continuous inspection scheme. Biometrika,41 (2): 100-115. http://dx.doi.org/10.2307/2333009

Poterba, J., and Summers, L., 1988. Mean reversion in stock prices: evidence and implications. Journal of Financial Economics, 22(1): 27-59. http://dx.doi.org/10.1016/0304-405X(88)90021-9

Savor, P., \& Wilson, M., 2013. How much do investors care about macroeconomic risk? evidence from scheduled economic announcements. Journal of Financial and Quantitative Analysis, 48(2): 343-375. http://dx.doi.org/10.1017/S002210901300015X

SEC. 2010. Recommendations regarding regulatory responses to the market events of May 6, 2010, Summary Report of the Joint CFTC-SEC Advisory Committee on Emerging Regulatory Issues. http://http://www.sec.gov/spotlight/sec-cftcjointcommittee/021811-report.pdf [Accessed 10/04/2014]

Stevens, G., 2013. Media release, Reserve Bank of Australia. http://www.rba.gov.au/media-releases/2013/mr-1310.html [Accessed on 11/15/2013] 